Document downloaded from:

http://hdl.handle.net/10251/59991

This paper must be cited as:

Portoles Flaj, JM.; Serra Mercé, E.; Romero, ML. (2013). Influence of ultra-high strength infill in slender concrete-filled steel tubular columns. Journal of Constructional Steel Research. 86:107-114. doi:10.1016/j.jcsr.2013.03.016.

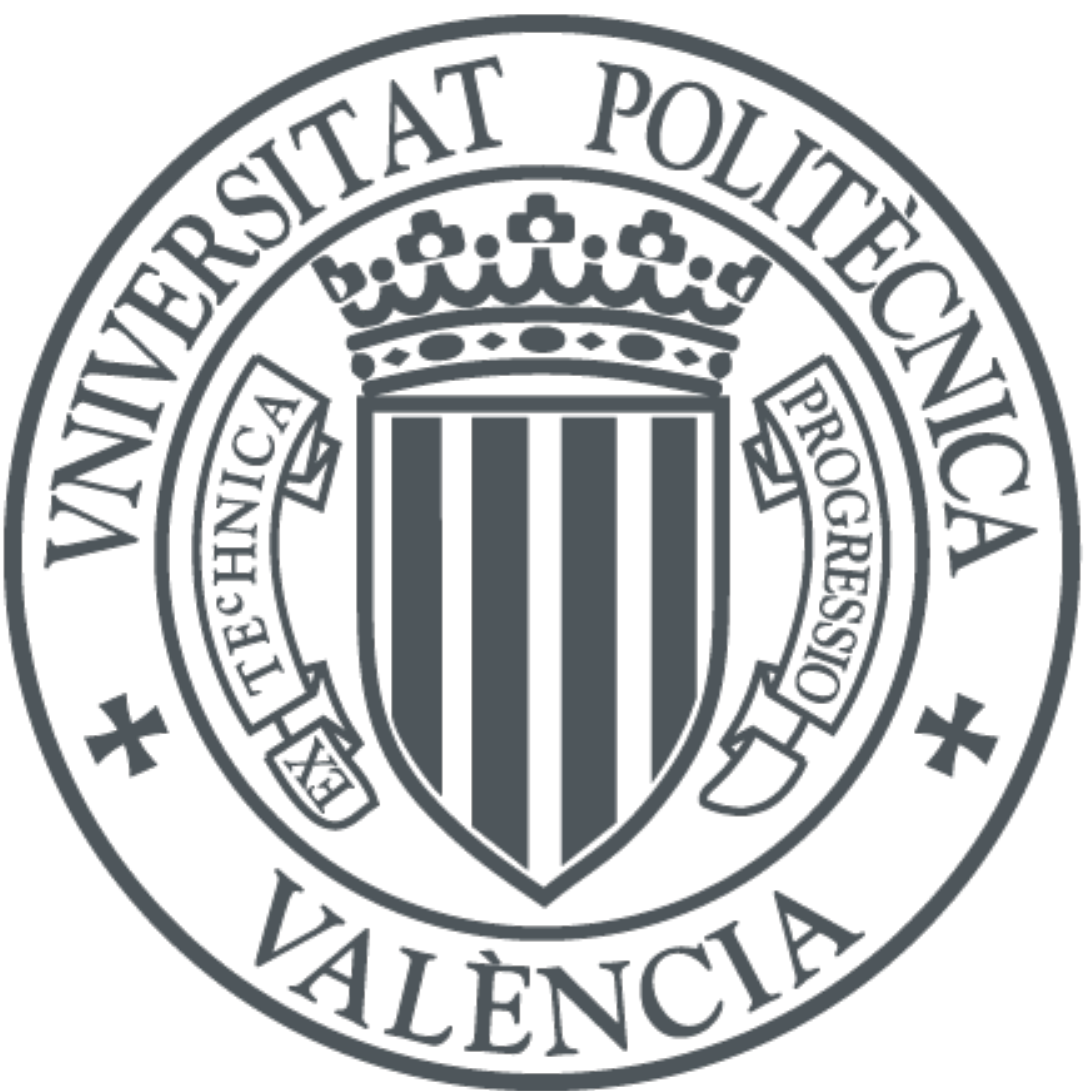

The final publication is available at

http://dx.doi.org/10.1016/j.jcsr.2013.03.016

Copyright Elsevier

Additional Information 
Portolés JM, Serra E, Romero ML*. Influence of ultra-high strength infill in slender concrete-filled steel tubular columns. Journal of constructional steel research 2013;86:107-114.

\title{
Influence of ultra-high strength infill in slender concrete-filled steel tubular
} columns

\author{
J.M. Portolés ${ }^{\mathrm{a}}$, E.Serra $^{\mathrm{b}}$ and M.L. Romero ${ }^{\mathrm{b} *}$ \\ a Department of Mechanical Engineering and Construction, Universitat Jaume I, \\ Castellón, Spain \\ b Instituto de Ciencia y Tecnología del Hormigón (ICITECH). Universitat \\ Politècnica de València, Spain
}

\begin{abstract}
This paper describes 24 tests conducted on slender circular tubular columns filled with normal, high, and ultra-high strength concrete for plain, bar reinforced and steel fiber reinforced columns. These were reinforced and subjected to both concentric and eccentric axial load. It is a continuation of a previous research paper [1], which presented test results on eccentrically loaded plain concrete columns. The test parameters are nominal strength of concrete $(30,90$ and $130 \mathrm{MPa})$, eccentricity e $(0,20$ and $50 \mathrm{~mm}$ ) and type of reinforcement. A comparison with the corresponding empty tubular columns is performed, as the aim of the paper is to analyze the influence of each type of infill and establish the best option for practical application. For the limited cases analyzed the results show that the addition of high or ultra-high strength infill is more useful for concentric loaded cases than for eccentric loaded ones, where it seems that the best design option is the utilization of bar reinforced concrete filling rather than steel fiber to reinforce CFST columns. The experimental ultimate load of each test was compared with the design loads from Eurocode 4, accurate for the eccentrically loaded tests.
\end{abstract}

Keywords: composite column, concrete-filled tubular columns, ultra-high strength concrete, buckling. 
Portolés JM, Serra E, Romero ML*. Influence of ultra-high strength infill in slender concrete-filled steel tubular columns. Journal of constructional steel research 2013;86:107-114.

*Corresponding author: Tel: +34-963877007(ext: 76742) Fax: +34-963879679, E-mail address: mromero@mes.upv.es

\section{NOTATION}

$\mathrm{e}=$ eccentricity

$\mathrm{L}=$ length

$\mathrm{D}=$ diameter

$\mathrm{t}=$ thickness

$\mathrm{f}_{\mathrm{c}}=$ strength of concrete

$f_{y}=$ yielding stress of steel

CFST $=$ concrete-filled steel tubular columns

HSS $=$ hollow steel sections

$\mathrm{NSC}=$ normal strength concrete

$\mathrm{HSC}=$ high strength concrete.

$\mathrm{UHSC}=$ ultra-high strength concrete

$\mathrm{CCR}=$ concrete contribution ratio

$\mathrm{Ac}=$ area of concrete

As $=$ area of steel

$E \cdot I=$ effective flexural stiffness of the composite section.

$\lambda=$ relative slenderness $=\sqrt{\frac{N_{p l}}{N_{c r}}}=\sqrt{\frac{A_{c} f_{c}+A_{s} f_{y}}{\frac{\pi^{2} E I}{L^{2}}}}$ 
Portolés JM, Serra E, Romero ML*. Influence of ultra-high strength infill in slender concrete-filled steel tubular columns. Journal of constructional steel research 2013;86:107-114.

\section{INTRODUCTION}

High strength concrete-filled steel tubular (CFST) columns have several properties, such as high stiffness, compression resistance and ductility, which make them a sustainable choice for high rise buildings or earthquake resistant structures. The high bearing capacity for a compact cross-section allows for greater story space, despite the slenderness of the columns. Their ductility improves the resistance of buildings and bridges in seismic areas. Inward local buckling of the tube is restricted by the core, while the brittle post-peak response of high strength concrete is mitigated by the tube.

Furthermore the fire resistance of CFST columns is enhanced, especially if they include rebars, even without additional protection [2].

The use of normal strength concrete (NSC) filled tubular columns has been studied and reported for several decades. Gourley et al. [3] presented a comprehensive research report, which compiled a large number of studies. Zhao et al. [4] recently published a book summarizing the research previously performed and comparing several design codes.

Studies of CFST members in recent years have focused on high performance materials, but they were mainly used for testing stub columns and concentric loading, in which the section response is more determinative than the overall buckling.

There are a few experimental campaigns on high strength CFST columns and slenderness, such as Rangan and Joyce[5], Kilpatric and Rangan[6, 7], and Johansson et al. $[8,9]$. The tests by Zeguiche and Chaoui[10] showed that the increase of concrete core strength is only effective for shorter columns and decreases with slenderness. De Oliveria et al. [11] also reached similar conclusions on circular slender CFST members. 
Portolés JM, Serra E, Romero ML*. Influence of ultra-high strength infill in slender concrete-filled steel tubular columns. Journal of constructional steel research 2013;86:107-114.

The combination of $\mathrm{D} / \mathrm{t}$ and steel strength in some of their tests was unable to develop confinement to the high strength concrete core.

The authors [1][12] concluded that it was clear that the use of HSC in slender concretefilled tubular columns does not offer the same improvement as that of NSC in composite behavior. They pointed out the usefulness of the concrete contribution for different values of slenderness, concrete strength, or confinement index for circular CFST columns. If a value of steel contribution ratio close to unity is used when designing the column, the performance can be optimized in terms of gain with respect to the empty column strength and confinement. In addition, Hernández-Figueirido et al.[13] described 36 experimental tests conducted on rectangular CFST columns filled with concrete up to $90 \mathrm{MPa}$ and subjected to axial compression and different eccentricities at both ends. The tests showed that the use of high strength concrete is more useful for the cases of non-constant bending moment since second order effects are reduced. However, when the aim is to obtain ductile behavior, the use of normal strength concrete is more suitable.

Not many experimental studies of CFST columns in the bibliography include reinforcing bars. Most of these were carried out to study the improvement in fire response [14], and did not focus on the strength at room temperature. Only Xiamuxi and Hasegawa [15] analyzed these columns numerically at room temperature and established the proper steel ratio, which will increase bearing capacity, ductility and toughness on reinforced concrete filled tubes at around 1-3\%.

There is an international research tendency to look for high strength materials when trying to increase the bearing capacity of composite columns. The use of high strength 
Portolés JM, Serra E, Romero ML*. Influence of ultra-high strength infill in slender concrete-filled steel tubular columns. Journal of constructional steel research 2013;86:107-114.

steel (fy $>460 \mathrm{MPa}$ ) is slowly being introduced into HSS columns as manufacturing companies have to modify the manufacturing process, although it should be commercially available in the near future. High or ultra-high strength infill are easily introduced as they only require modification of the mix proportions of concrete.

Eurocode 2, EN 1992-1-1 [16] defines concrete as high strength (HSC) when fc $>50$ $\mathrm{MPa}$ and as ultra-high strength (UHSC) when fc $>90 \mathrm{MPa}$.

The utilization of UHSC in columns is not very common and furthermore is usually combined with steel fiber reinforcement to obtain fc>120 MPa. These columns are extremely brittle and need this addition to improve post-peak behavior and increase ductility.

In the literature, studies about CFST columns filled with steel fiber reinforced concrete are relatively recent and have mainly been presented for NSC. Their interest is based on fibers which enhance the flexural behavior particularly for a specific eccentricity or slenderness, improving the fire resistance of the columns. However, Johansson [17] stated that the use of steel fibers in infill does not improve the performance of stub CFST columns at room temperature. Gopal and Manoharan[18] concluded that the addition of metallic fibers, when $\mathrm{L} / \mathrm{D}>20$, and with eccentricity, improves energy absorption and ductility and provides slightly higher resistance, but decreases the response of columns with lower eccentricity. Tao et al. [19] found that more ductile behavior can also be obtained in stub columns by increasing the amount of steel fibers. Tokgoz and Dundar [20] reached similar conclusions using concrete reinforced with steel fibers and concrete strength close to $58 \mathrm{MPa}$. The use of this concrete improves ductility but has little effect on the ultimate strength of rectangular CFST columns. 
Portolés JM, Serra E, Romero ML*. Influence of ultra-high strength infill in slender concrete-filled steel tubular columns. Journal of constructional steel research 2013;86:107-114.

Kodur et al. [21] concluded that steel fiber reinforced concrete contributes effectively to the fire resistance of concrete-filled steel columns, whereas other authors have not observed such differences. Romero et al. [22] pointed out that this improvement does not occur if slenderness is high.

The current design method of Eurocode 4 [23] does not cover the use of these types of infill for the design of CFST columns, as concrete strength is limited to 50MPa (cylinder) and the reinforcement ratio to $6 \%$, while steel fiber reinforced concrete is not considered. Accordingly, Eurocode 4 has to be reviewed for the use of these innovative infills.

Recently, Liew and Xiong [24] presented a very interesting experimental investigation testing ultra-high strength composite columns. However, these tests focused on stub columns and the UHSC was a commercial pre-blended mix, a kind of mortar material. They reached the conclusion that the steel fibers help to improve the ductility of composite columns, and that Eurocode 4 can be safely extended to predict their resistance if the confinement effect is ignored.

However, their conclusions need to be extended to slender columns.

The objective of this study is to analyze the influence of each type of infill in order to establish which is the best option for practical design. To do so an experimental campaign was also carried out to check the applicability of Eurocode 4.

\section{EXPERIMENTAL PROGRAM}

Twenty-four tests were carried out in this experimental program on normal, high and ultra-high strength concrete-filled steel tubular columns. These tests were designed to investigate the effects of three major parameters on their behavior: type of infill (plain 
Portolés JM, Serra E, Romero ML*. Influence of ultra-high strength infill in slender concrete-filled steel tubular columns. Journal of constructional steel research 2013;86:107-114.

concrete, bar reinforced concrete and steel fiber reinforced), eccentricity (e), and strength of concrete $\left(f_{c}\right)$. The ranges of these parameters were selected outside construction practice ranges, where the authors noted a lack of awareness and experimental research. The experimental program is a continuation of a previous study [1], where test results on eccentrically loaded plain concrete columns were presented. Table 1 summarizes the experimental data. As can be observed, there are fewer tests for high strength concrete (HSC), as the influence of ' $\mathrm{fc}$ ' was studied for the larger eccentricities only. There are also two specimens (tests 13 and 20) which were repeated (tests 14 and 21) because they presented strange behavior during the experimental test, bending in the opposite direction. In addition, some tests were repeated to check the reliability of the experimental program (tests 16 and 23).

Column length was $2135 \mathrm{~mm}$ in all tests as, despite the 2 meter length of the tubes, the distance between the hinges required the addition of a special assembly length of $135 \mathrm{~mm}$. The nominal cross-section of the circular tubes (diameter ' $\mathrm{D}$ ' $\times$ thickness ' $\mathrm{t}$ ') was $159 \times 6 \mathrm{~mm}$. The thickness of the tubes was selected in order to avoid local buckling following Eurocode 4. The nominal strength of concrete varied from 30, 90 to $130 \mathrm{MPa}$ (normal strength concrete, NSC, high strength concrete, HSC, and ultra-high strength concrete, UHSC respectively). The axial load was applied with the same eccentricity at both ends with values of 0,20 and $50 \mathrm{~mm}$. All the specimens were manufactured at the Universitat Politècnica de València, Spain and later tested at the Universitat Jaume I in Castellón, Spain.

The range of the parameters tested was:

- $\mathrm{e} / \mathrm{D}=\{0,0.13,0.31\}$ with $\mathrm{e}=\{0,20,50\} \mathrm{mm}, \mathrm{D}=159 \mathrm{~mm}, \mathrm{t}=6 \mathrm{~mm}, \mathrm{~L}=2135 \mathrm{~mm}$.

- Nominal 'fc' $=\{30,90,130\} \mathrm{MPa}$ and real ' $\mathrm{fc}$ ' $\{35.15-131.21\} \mathrm{MPa}$. 
Portolés JM, Serra E, Romero ML*. Influence of ultra-high strength infill in slender concrete-filled steel tubular columns. Journal of constructional steel research 2013;86:107-114.

- $\quad f y=\{365.73-493.82\} \mathrm{MPa}$

- Infill $=\left\{\right.$ plain concrete, rebars $4 \varnothing 12$, steel fibers $40 \mathrm{~kg} / \mathrm{m}^{3}$, steel fibers $\left.100 \mathrm{~kg} / \mathrm{m}^{3}\right\}$

It can be observed in Table 1 that all the specimens were slender as their relative slenderness, defined in Eurocode 4 (see section on notation), is higher than 0.5

\subsection{Material properties}

The cold-formed and welded steel tubes were supplied by a local dealer. The steel grade was S275JR (nominal yield strength of $275 \mathrm{MPa}$ ) and the real strength $\left(\mathrm{f}_{\mathrm{y}}\right)$ of the empty tubes was obtained by coupon test, as shown in Table 1. It is worth noting that although the nominal yield strength of steel was the same for all the circular HSS, the actual ' $\mathrm{f}_{\mathrm{y}}$ ' was much higher in all cases, and there was a very wide scatter, close to 360 $\mathrm{MPa}$ in some specimens and close to 490 in others, causing initial confusion in the results. All the samples were cut in the same location of the cross section, $90^{\circ}$ from the welding area.

The modulus of elasticity 'Es' of the steel was set following European standards with a value of $210 \mathrm{GPa}$.

Normal, high and ultra-high strength concretes.

The concrete was batched in the laboratory with three different nominal strengths: 30 $\mathrm{MPa}, 90 \mathrm{MPa}$ and $130 \mathrm{MPa}$; Table 2 summarizes the mix proportions of the batches. The concrete compressive strength ' $\mathrm{f}_{\mathrm{c}}$ ' was determined thanks to standard tests carried out on both the $150 \times 300 \mathrm{~mm}$ cylinder and the $100 \mathrm{~mm}$ cube. The strength of the cubic samples was translated to the cylindrical equivalent using Eurocode 2. All samples were tested on the same day as the column was tested, as shown in Table 1. 
Portolés JM, Serra E, Romero ML*. Influence of ultra-high strength infill in slender concrete-filled steel tubular columns. Journal of constructional steel research 2013;86:107-114.

It can be observed that the real ' $\mathrm{fc}$ ' also has a wide scatter for the UHSC specimens and the desired strengths $(120-130 \mathrm{MPa})$ are only achieved when 40 and $110 \mathrm{Kg} / \mathrm{m}^{3}$ steel fibers are added to the mix proportions. 
Portolés JM, Serra E, Romero ML*. Influence of ultra-high strength infill in slender concrete-filled steel tubular columns. Journal of constructional steel research 2013;86:107-114.

Reinforced concrete.

The reinforced specimens (RC) followed the arrangement presented in Fig. 1.a and Fig. 1.b, with four longitudinal reinforcing bars of $12 \mathrm{~mm}$ diameter and $6 \mathrm{~mm}$ stirrups with $30 \mathrm{~cm}$ spacing along the column length. The geometrical reinforcement ratio $\left(A_{\mathrm{s}} / A_{\mathrm{c}}\right)$ was equal to $2.67 \%$, as recommended by Xiamuxi and Hasegawa [15]. The real yield strength of the reinforcing steel $\left(f_{\mathrm{s}}\right)$ was $567 \mathrm{MPa}$.

Steel fiber reinforced concrete.

As one of the aims of the investigation was to study specimens with good ductile behavior, steel fibers with a high yield strength and high elongation were selected. The shape of the fibers was that of an open staple, Fig. 2.a. For the NSC, the fibers were $35 \mathrm{~mm}$ long and $0.55 \mathrm{~mm}$ in diameter, with a yield strength of $1100 \mathrm{MPa}$, while for the case of HSC and UHSC the steel fibers were $30 \mathrm{~mm}$ long and $0.4 \mathrm{~mm}$ in diameter, with a yield strength of $2300 \mathrm{MPa}$. In order to observe the differences in behavior of the columns, two different volumetric ratios $\left(40 \mathrm{~kg} / \mathrm{m}^{3}\right.$ and $\left.110 \mathrm{~kg} / \mathrm{m}^{3}\right)$ were added to the concrete batches. The concrete with steel fibers required extra super-plasticizer to correct the workability of the batch, Fig. 2.c.

\subsection{Fabrication of columns}

A $10 \mathrm{~mm}$ thick steel plate was welded to the bottom end of the column in order to facilitate the casting of the fresh concrete. Concrete was then poured into the vertical column and shaken with an external vibrator. Once the casting was complete, the specimens were covered with a wet cloth and plastic film for one week. Prior to testing, a second steel plate was welded to the top end of the column. Pouring the concrete into the UHSC specimens with $110 \mathrm{Kg} / \mathrm{m}^{3}$ of steel fibers was very complex, and in some 
Portolés JM, Serra E, Romero ML*. Influence of ultra-high strength infill in slender concrete-filled steel tubular columns. Journal of constructional steel research 2013;86:107-114.

cases the concrete began to harden in less than 15 minutes, which would complicate practical application in real building, but not in precast construction.

\subsection{Test Setup and procedure}

All the specimens were tested in a special $5000 \mathrm{kN}$ testing frame, in a horizontal position, Fig. 1.c. The pinned ends were designed to apply the same eccentricities at both ends, Fig. 1.d and Fig. 1.e. For the cases of axial compression without eccentricity, a small initial eccentricity of $2 \mathrm{~mm}$ was added to avoid unstable loading. More details of the setup can be found in [1] and [13].

Linear variable displacement transducers were used to measure the deflection at five points along the column $(0.25 \mathrm{~L}, 0.375 \mathrm{~L}, 0.5 \mathrm{~L}, 0.625 \mathrm{~L}$ and $0.75 \mathrm{~L})$, Fig. 1.f. Electric strain gauges were bonded halfway along the column to the longitudinal reinforcing bars and the steel tube surface in order to measure longitudinal strains. Their position, at $0^{\circ}$ and $180^{\circ}$, can be observed in Fig. 1.b.

Once the specimen was put in place, displacement control tests were carried out in order to measure post-peak behavior.

\section{ANALYSIS OF THE RESULTS}

\subsection{Influence of eccentricity and strength of concrete.}

The maximum axial load of all specimens (Nexp) is listed in Table 1 and the axial force versus mid-span displacement response of some tests is presented in Fig. 3. The general tendency of the curves is as expected: when the eccentricity increases, Fig. 3.a, the maximum load decreases. The effect of concrete strength is observed in Fig. 3.b, where it can be inferred that when concrete strength is increased, so is the axial load. 
Portolés JM, Serra E, Romero ML*. Influence of ultra-high strength infill in slender concrete-filled steel tubular columns. Journal of constructional steel research 2013;86:107-114.

\section{2.-Influence of infill}

The influence of infill is analyzed from Fig. 4 to Fig. 6 where the 24 tests are presented in series, separated according to strength of concrete and eccentricity.

Fig. 4 presents the tests on normal strength concrete (NSC) for the three different eccentricities studied ( $=0 \mathrm{~mm}, \mathrm{e}=20 \mathrm{~mm}$ and $\mathrm{e}=50 \mathrm{~mm})$. The axially loaded columns $(\mathrm{e}=0)$ and columns with eccentricity $\mathrm{e}=20 \mathrm{~mm}$ were filled only with plain concrete or bar reinforced concrete, while those with $\mathrm{e}=50 \mathrm{~mm}$ eccentricity were also filled with steel fiber reinforced concrete $\left(40 \mathrm{~kg} / \mathrm{m}^{3}\right.$ and $\left.110 \mathrm{~kg} / \mathrm{m}^{3}\right)$.

Additionally, Fig. 5 shows the effect of infill for the high strength concrete (HSC) specimens with large eccentricities and Fig. 6 presents the comparison of the ultra-high strength concrete tests (UHSC), also for $\mathrm{e}=0,20$ and $50 \mathrm{~mm}$.

In all the cases in Fig. 4 a major difference can be observed between bar reinforced concrete-filled CFST and plain concrete-filled CFST. However this enhancement is not observed in Fig. 5 or Fig. 6, where the differences are smaller. Although initially it could be inferred that the origin of this behavior is due to the difference between NSC and HSC or UHSC, it is actually due to the difference in the yield strength ' $\mathrm{f}_{\mathrm{y}}$ ' of the steel tubes in Fig. 4, due to the use of commercial tubes of the same quality (S275JR) but different mild. So, observations from these figures can be subjective. The measurement of concrete contribution ratios (CCR) in the following section will help clarify this since it takes the axial load that an empty tube of the same characteristics can resist as a reference value.

Fig. 4.a and Fig. 6.a are the axially loaded cases for NSC and UHSC specimens respectively and, as the eccentricity is almost null, the eccentricity due to bow 
Portolés JM, Serra E, Romero ML*. Influence of ultra-high strength infill in slender concrete-filled steel tubular columns. Journal of constructional steel research 2013;86:107-114.

imperfections becomes more important, presenting unstable behavior in specific cases . It is worth noting that in these cases an eccentricity of $2 \mathrm{~mm}$ was added to prevent this situation.

The effect of the steel fibers on the behavior of CFST columns is completely different in the case of NSC from in the case of HSC or UHSC. When the strength of concrete is low (NSC), the steel fibers can substitute the reinforcing bars because the behavior of both cases is similar, Fig. 4. However the addition of steel fibers does not help in the case of high or ultra-high strength concrete, Fig. 5 or Fig. 6.c. This statement could initially provide erroneous results as it has been demonstrated that steel fiber reinforced UHSC shows better behavior than plain UHSC. However, these columns are slender, and global behavior predominates over section behavior, so the second order effects neglect any improvement that the fibers might contribute to. In fact, in the case of the axial load of steel fiber reinforced UHSC (40 or $110 \mathrm{~kg} / \mathrm{m}^{3}$ ), as shown in Fig. 6, it is lower than in tests involving plain concrete. Again, this reduction is due to a lower value of ' $f_{\mathrm{y}}$ ' and not due to the infill behavior.

\section{3.- Post-peak behavior.}

From previous figures, Fig. 3 to Fig. 6, clear differences in post-peak behavior can be observed between normal, high and ultra-high strength concrete. The slope of the postpeak descending branch is more abrupt for the latter cases, as was expected. However, the higher the eccentricity, the more ductile the behavior. In these cases the descending branch in post-peak behavior is almost parallel, so it can be stated that eccentricity has greater influence on ductility than the concrete strength. The type of infill does not seem to be a major factor given the slenderness of the columns. 
Portolés JM, Serra E, Romero ML*. Influence of ultra-high strength infill in slender concrete-filled steel tubular columns. Journal of constructional steel research 2013;86:107-114.

\section{INFLUENCE OF INFILL IN THE BUCKLING RESISTANCE OF SLENDER CFST COLUMNS}

\section{Concrete Contribution Ratio (CCR).}

One of the objectives of this paper is to establish the influence of the type of infill on the resistance of slender concrete-filled tubular columns, carried out a comparison with hollow steel sections. In a previous paper, Portolés et al. [1] stated that for slender columns with higher eccentricity, increasing the strength of the concrete too much is of no great use because no increment in the maximum load was obtained when comparing between 70 and $90 \mathrm{MPa}$. However, the use of HSC composite columns was still of interest as they resulted in better ductile behavior. In this paper the variation of infill is not only associated with the strength of concrete but also with the addition of rebars or steel fibers.

To measure this influence the concrete contribution ratio (CCR) is defined as the ratio between the maximum load of the composite column and the empty hollow steel member. It denotes the gain which could be made by using concrete-filled columns rather than bare steel columns:

$$
\mathrm{CCR}=\frac{\mathrm{N}_{\text {max,exp }}}{\mathrm{N}_{\text {max,hollow }}}
$$

The value $\mathrm{N}_{\text {max,hollow }}$ is obtained from Eurocode 3 [25] while $\mathrm{N}_{\max \text {,exp }}$ is obtained from the maximum load of the experimental tests, as listed in Table 1. The concrete contribution ratio has been graphically analyzed in terms of concrete strength (fc) and eccentricity, comparing the different types of infill, as shown in Fig. 7. In this figure, the influence of variation of ' $f_{\mathrm{y}}$ ' is therefore eliminated. 
Portolés JM, Serra E, Romero ML*. Influence of ultra-high strength infill in slender concrete-filled steel tubular columns. Journal of constructional steel research 2013;86:107-114.

As the eccentricity increases, the CCR decreases, and mainly in the case of HSC and UHSC it is more effective to fill the tube with concrete when the load is centered.

In general, CFST filled with bar reinforced concrete improves the CCR, but in the case of $\mathrm{e}=0 \mathrm{~mm}$, reinforcement has a little effect. That is, bar reinforced concrete is obviously more effective in situations with higher bending moments. Bar reinforcement is also more effective in NSC than in HSC, and contributes less to the CCR.

While the steel fiber infill has a positive effect on the CCR when ' $\mathrm{fc}$ ' is lower, it has little effect on this parameter when the strength of concrete is increased. This statement can only be backed by the workability of the fresh concrete with steel fibers which it drastically reduces. Another possible justification is that due to the reduction of the lateral deformation of the concrete core due to the steel fibers, the effect of confinement is reduced, as is the maximum load. However, this hypothesis requires further experimental tests, focusing on stub columns, before it can be confirmed.

In a comparison of steel fiber reinforced concrete with bar reinforced concrete, the former has lower CCR than the latter. If all the fibers are arranged longitudinally and homogenously in the concrete mass, assuming an equivalent bar reinforcement of four bars, the diameter of these bars has to be $4.5 \mathrm{~mm}$ and $7.5 \mathrm{~mm}$ for $40 \mathrm{~kg} / \mathrm{m}^{3}$ and $110 \mathrm{~kg} / \mathrm{m}^{3}$ for the respective fiber contents. This is half the diameter of the reinforcement considered. While $40 \mathrm{~kg} / \mathrm{m}^{3}$ is the usual fiber content, the higher quantity of $110 \mathrm{~kg} / \mathrm{m}^{3}$ renders the concrete batch unworkable, as the addition of a higher volumetric ratio of steel fibers hinders the correct workability of the concrete. Thus for the limited cases analyzed, the infill with bar reinforcement is a better design solution than steel fiber reinforced concrete for slender CFST columns. Romero et al. [22] [26] studied the fire 
Portolés JM, Serra E, Romero ML*. Influence of ultra-high strength infill in slender concrete-filled steel tubular columns. Journal of constructional steel research 2013;86:107-114.

behavior of columns similar to those presented in this study and found that the use of steel fiber reinforced concrete does not improve the fire response of slender columns.

Within the limited cases analyzed in this study, it seems that steel fibers can substitute the reinforcement only in NSC experiments but not in HSC or UHSC tests.

An additional (and obvious) statement can be inferred from Fig. 7. HSC or UHSC is used more efficiently under axial load with small eccentricity. When eccentricity increases, the bending moment increases and the use of bar reinforcement, thicker steel tubes, or higher yield strengths could be the best option to improve resistance. Steel fiber reinforced concrete does not always improve the behavior of CFST columns at room temperature or under fire conditions, as it is less workable and cannot actually be recommended until the deterioration of the resistance of such columns is clarified by further study.

\section{COMPARISON USING EUROCODE 4}

A comparison was performed with the simplified method of Eurocode 4 [23] based on the experimental results of the slender CFST columns with plain concrete, bar reinforced concrete, and steel fiber reinforced concrete. It is worth noting that HSC and UHSC tests were outside the scope of this standard which is limited to $50 \mathrm{MPa}$ of cylinder concrete strength. In addition, this method does not consider the possibility of adding steel fiber reinforced concrete. The experiments in this study aim to clarify whether Eurocode 4 is still applicable to these types of infill.

In actual fact, since these tests have values of $\lambda \geq 0.5$, Table 1 , the increment in the resistance of the cross-section due to the confinement effect is ignored. In addition the partial safety factor for steel and concrete is fixed at 1. 
Portolés JM, Serra E, Romero ML*. Influence of ultra-high strength infill in slender concrete-filled steel tubular columns. Journal of constructional steel research 2013;86:107-114.

Table 1 shows a comparison between the experiments and the design load $\left(\mathrm{N}_{\mathrm{exp}} / \mathrm{N}_{\mathrm{EC} 4}\right)$, where a value higher than 1 means that the design method is safe. Tests number 13 and 20 failed, bending in the opposite direction from that expected, so they have been excluded from the average. The ratio shows a mean error of 1.00 and a standard deviation of 0.076 , which means that the provisions are in good agreement with the experiments. Fig. 8 shows the comparison of both loads, and it can be observed that most of the errors are within a margin of $15 \%$, although some observations should be made. Fig. 9 represents the ratio $\mathrm{N}_{\mathrm{exp}} / \mathrm{N}_{\mathrm{EC} 4}$ versus the concrete strength for the different types of infill and eccentricities. Fig. 9.a compares the error for the cases of null eccentricity. Apart from the tests that were discounted, the dispersion is higher, meaning that the determination of the eccentricity due to initial imperfections is very important for these tests.

The results show for the limited cases analyzed of plain concrete tests that when the strength of concrete ' $\mathrm{fc}$ ' increases the provision is safer, but this trend is different for the other types of infill. In the case of bar reinforced concrete and steel fiber reinforced concrete with an eccentricity of $50 \mathrm{~mm}$ the ratio decreases, still staying within a margin of $10 \%$.

Finally it is observed that errors for UHSC were less scattered than for the other groups, Fig. 9.c.

In general, it can be concluded that Eurocode 4 [23] can be safely extended for HSC and UHSC columns if the load is applied eccentrically, i.e. using interaction diagrams. However, Eurocode 4 is less accurate in predicting cases where the eccentricity is null, 
Portolés JM, Serra E, Romero ML*. Influence of ultra-high strength infill in slender concrete-filled steel tubular columns. Journal of constructional steel research 2013;86:107-114.

i.e. using European buckling curves. Accordingly, the authors consider that it is necessary to provide more data to achieve reliable results to find out if the error is due to the influence of the real bow imperfections in the experiments or comes from the European buckling curves, which are applied in these cases. To aid this study further experiments are needed in combination with numerical models.

\section{CONCLUSIONS}

In this paper 24 experimental tests on slender concrete-filled steel tubular columns were conducted on normal, high, and ultra-high strength concrete for plain, bar reinforced and steel fibers reinforced and subjected both to concentric and eccentric axial load. The objective of the study is to analyze the influence of different types of infill in order to establish which is the best option for practical design.

From the experiments it can be observed that when the strength of concrete is low (NSC) the steel fibers can substitute the reinforcement but the addition of steel fibers is not as useful in the case of high or ultra-high strength concrete (HSC or UHSC).

It is also worth noting that for slender members an improvement in ductility is easily obtained with eccentricity but not with concrete strength or type of infill.

The addition of high or ultra-high strength infill is more useful in the case of concentric loading than in the case of eccentric loading, where it seems that the best design option is the utilization of bar reinforced concrete filling rather than steel fiber reinforced CFST columns.

A comparison using the simplified method of Eurocode 4 [23] was also performed, concluding that for slender columns this can be safely extended for HSC and UHSC columns if the load is applied eccentrically, i.e. using interaction diagrams. However, 
Portolés JM, Serra E, Romero ML*. Influence of ultra-high strength infill in slender concrete-filled steel tubular columns. Journal of constructional steel research 2013;86:107-114.

Eurocode 4 is less accurate in predicting cases where eccentricity is null, and the European buckling curves for such cases should be carefully studied due to the scattered errors found.

\section{ACKNOWLEDGEMENTS}

The authors wish to express their sincere gratitude to the Spanish Ministry of Science and Innovation for help provided through project BIA 2009_09411, Plan E, and to the European Community for FEDER funds.

\section{REFERENCES}

[1] J.M. Portoles, M.L. Romero, J.L. Bonet, F.C. Filippou, Experimental study of high strength concrete-filled circular tubular columns under eccentric loading, Journal of Constructional Steel Research 2011; 67: 623-633.

[2] L. Twilt, R. Hass, W. Klingsch, M. Eduards, D. Dutta, Design guide for structural hollow section columns exposed to fire. CIDECT (Comité International pour le Développementetl'Etude de la Construction Tubulaire). Cologne, Germany: Verlag TÜV Rheinland;, Cologne, Germany: Verlag TÜV Rheinland;, 1996.

[3] B.C. Gourley, C. Tort, M.D. Denavit, P.H. Schiller, J.F. Hajjar, A Synopsis of Studies of the Monotonic and Cyclic Behavior of Concrete-Filled Steel Tube Beam-Columns, Department of Civil and Environmental Engineering, University of Illinois at Urbana-Champaign, Urbana, Illinois, 2008.

[4] X.-L. Zhao, L.-H. Han, H. Lu, Concrete-filled Tubular Members and Connections, CRC Press, 2010. 
Portolés JM, Serra E, Romero ML*. Influence of ultra-high strength infill in slender concrete-filled steel tubular columns. Journal of constructional steel research 2013;86:107-114.

[5] Rangan BV, Joyce M, Strength of eccentrically loaded Slender stell tubular columns filled with High-strength concrete, ACI Structural Journal 1992; 89:676681.

[6] Kilpatrick AE, Rangan BV, Tests on High-Strength Concrete-Filled Steel Tubular Columns, ACI Structural Journal 1999; 96:268-274.

[7] Kilpatrick AE, Rangan BV, Influence of interfacial shear transfer on behavior of concrete-filled steel tubular columns, ACI STRUCTURAL JOURNAL 1999; 96: $642-648$.

[8] Johansson M, Gylltoft K, Structural behavior of slender circular steel-concrete composite columns under various means of load application, Steel \& Composite Structures 2001; 1: 393-410.

[9] Johansson M, The efficiency of passive confinement in CFT columns, Steel \& Composite Structures 2002; 2: 379-396.

[10] Zeghiche J, Chaoui K, An experimental behaviour of concrete-filled steel tubular columns, Journal of Constructional Steel Research 2005; 61: 53-66.

[11] De Oliveira WLA., De Nardin S, De Cresce El Debs ALH, El Debs MK, Influence of concrete strength and length/diameter on the axial capacity of CFT columns, Journal of Constructional Steel Research 2009; 65: 2103-2110.

[12] Portolés JM, Romero ML, Filippou FC, Bonet JL, Simulation and design recommendations of eccentrically loaded slender concrete-filled tubular columns, Engineering Structures 2011; 33: 1576-1593.

[13] Hernández-Figueirido D, Romero ML, Bonet JL, Montalvá JM, Ultimate capacity of rectangular concrete-filled steel tubular columns under unequal load eccentricities, Journal of Constructional Steel Research 2012; 68 :107-117. 
Portolés JM, Serra E, Romero ML*. Influence of ultra-high strength infill in slender concrete-filled steel tubular columns. Journal of constructional steel research 2013;86:107-114.

[14] Lie TT, Fire resistance of circular steel columns filled with bar-reinforced concrete, Journal of Structural Engineering - ASCE 1994; 120 :1489-1509.

[15] Xiamuxi A, Hasegawa A, A study on axial compressive behaviors of reinforced concrete filled tubular steel columns, Journal of Constructional Steel Research $2012 ; 76: 144-154$.

[16] CEN European Comittee of Standarization, EN 1992-1-1:2004 Eurocode 2 Design of concrete structures. Part 1-1. General rules and rules for buildings, 2004.

[17] M. Johansson, Composite action and confinement effects in tubular steel-concrete columns, Thesis for the degree of doctor of philosophy, Department of Structural Engineering, Concrete Structures, Chalmers University of technology, Göteborg, Sweden, 2002.

[18] Gopal SR, Manoharan PD, Experimental behaviour of eccentrically loaded slender circular hollow steel columns in-filled with fibre reinforced concrete, Journal of Constructional Steel Research 2006; 62: 513-520.

[19] Tao Z, Uy B, Han LH, Wang ZB, Analysis and design of concrete-filled stiffened thin-walled steel tubular columns under axial compression, Thin-Walled Structures 2009; 47: 1544-1556.

[20] Tokgoz S, Dundar C, Experimental study on steel tubular columns in-filled with plain and steel fiber reinforced concrete, Thin-Walled Structures 2010; 48: 414 422.

[21] Kodur VKR, Lie T, Experimental studies on the fire resistance of hollow steel columns filled with high-strength concrete, National Research Council of Canada (NRCC), Ottawa, Canada, 2005. 
Portolés JM, Serra E, Romero ML*. Influence of ultra-high strength infill in slender concrete-filled steel tubular columns. Journal of constructional steel research 2013;86:107-114.

[22] Romero ML, Moliner V, Espinos A, Ibanez C, Hospitaler A, Fire behavior of axially loaded slender high strength concrete-filled tubular columns, J. Constr. Steel. Res. 2001; 67 :1953-1965.

[23] European Comittee of Standarization, EN 1994-1-1:2004 Eurocode 4: Design of composite steel and concrete structures Part 1-1: General rules and rules for buildings, 2004.

[24] Liew JYR, Xiong D X. Ultra-High Strength Concrete Filled Composite Columns for Multi-Storey Building Construction. Advances in structural engineering 2012;15(9):1487-1503.

[25] European Comittee of Standarization, EN 1993-1-1:2005 Eurocode 3 Design of steel structures. Part 1-1. General rules., 2005.

[26] Moliner V, Espinos A, Romero ML, Hospitaler A, Fire behavior of eccentrically loaded slender high strength concrete-filled tubular columns, Journal of Constructional Steel Research 2013; submitted for publication. 
Portolés JM, Serra E, Romero ML*. Influence of ultra-high strength infill in slender concrete-filled steel tubular columns. Journal of constructional steel research 2013;86:107-114.
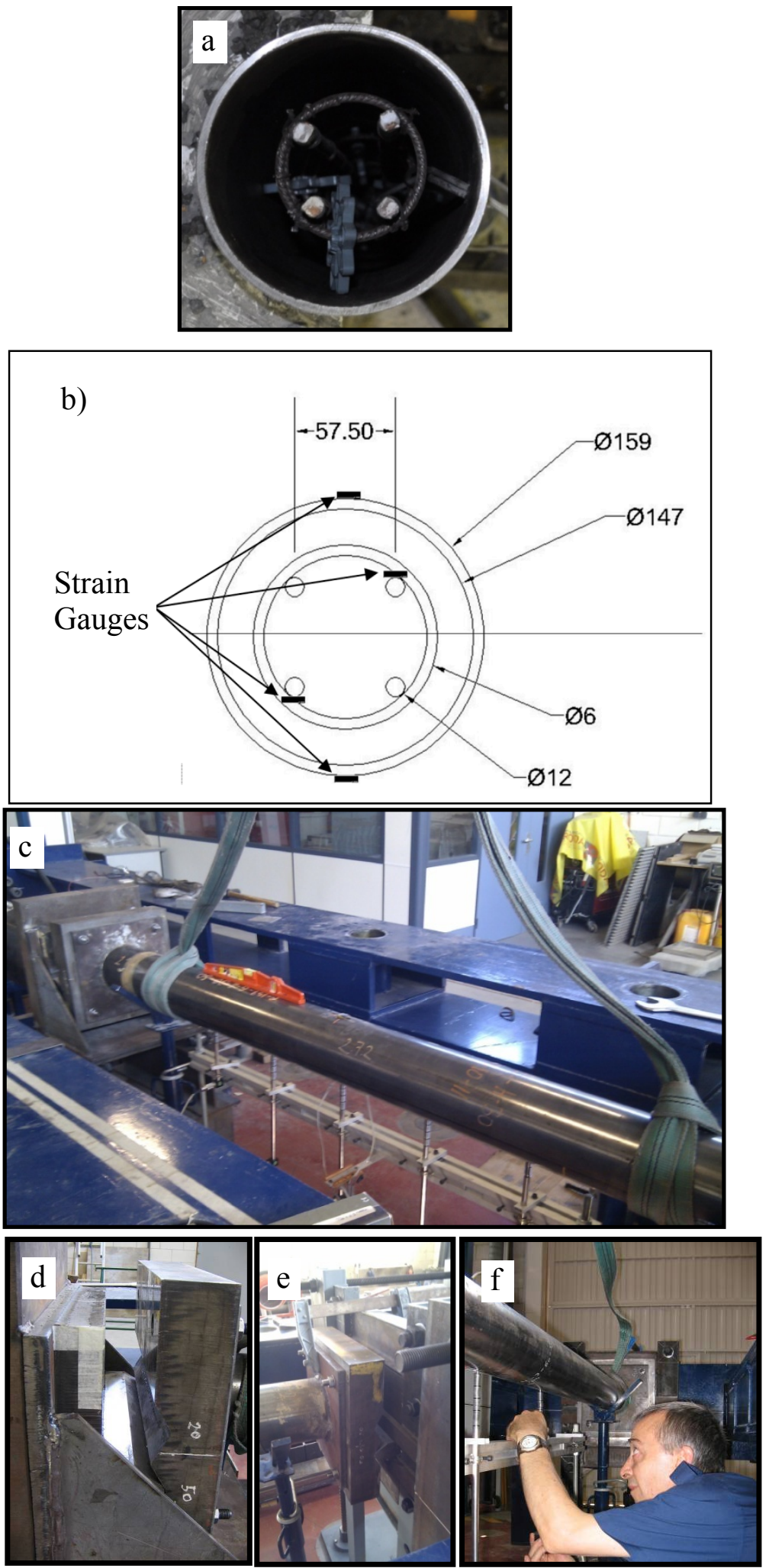

Fig. 1. Schematic cross-section and gauge installation 
Portolés JM, Serra E, Romero ML*. Influence of ultra-high strength infill in slender concrete-filled steel tubular columns. Journal of constructional steel research 2013;86:107-114. 
Portolés JM, Serra E, Romero ML*. Influence of ultra-high strength infill in slender concrete-filled steel tubular columns. Journal of constructional steel research 2013;86:107-114.

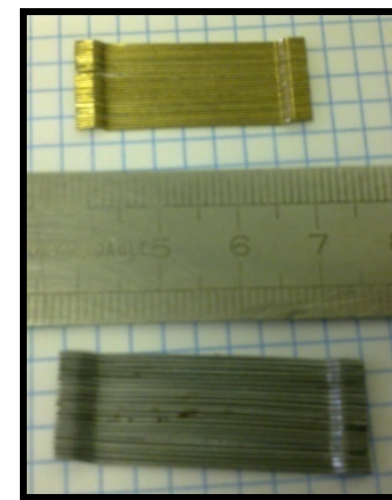

a)

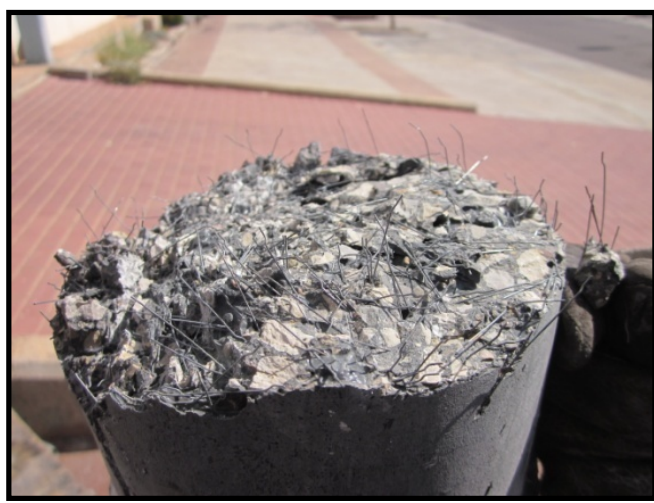

b)

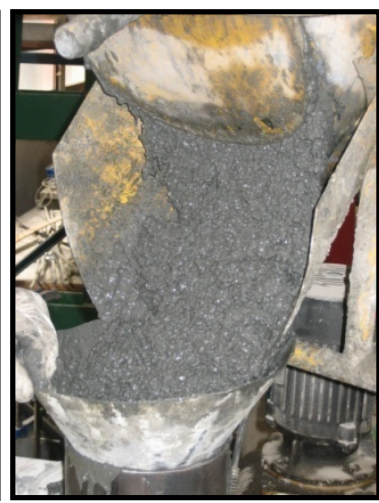

c)

Fig. 2. Steel fiber reinforced ultra-high strength concrete 
Portolés JM, Serra E, Romero ML*. Influence of ultra-high strength infill in slender concrete-filled steel tubular columns. Journal of constructional steel research 2013;86:107-114.

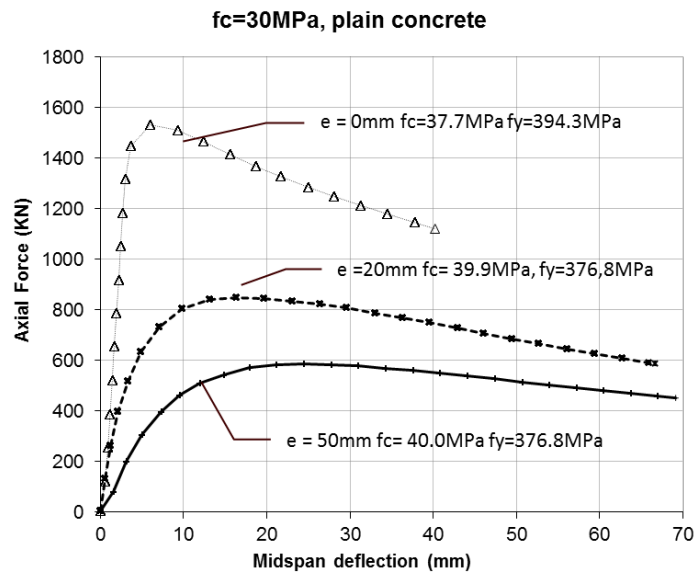

a)

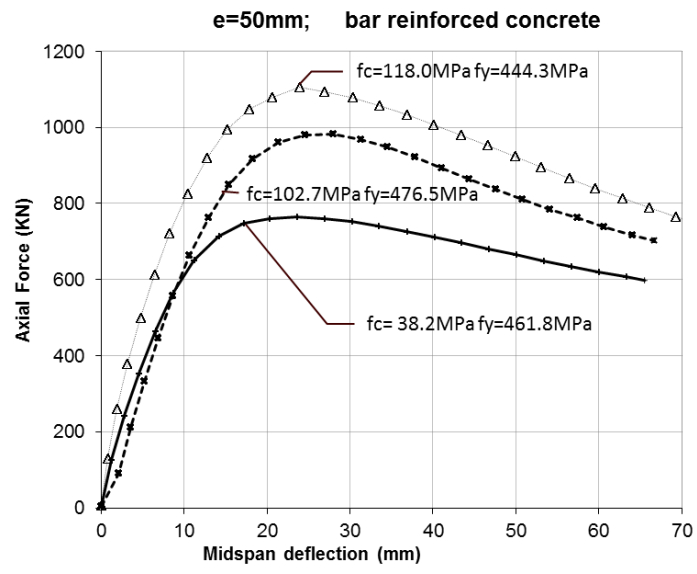

b)

Fig. 3. Axial load versus midspan displacement series: a) Effect of eccentricity. b) Influence of strength of concrete. 
Portolés JM, Serra E, Romero ML*. Influence of ultra-high strength infill in slender concrete-filled steel tubular columns. Journal of constructional steel research 2013;86:107-114.

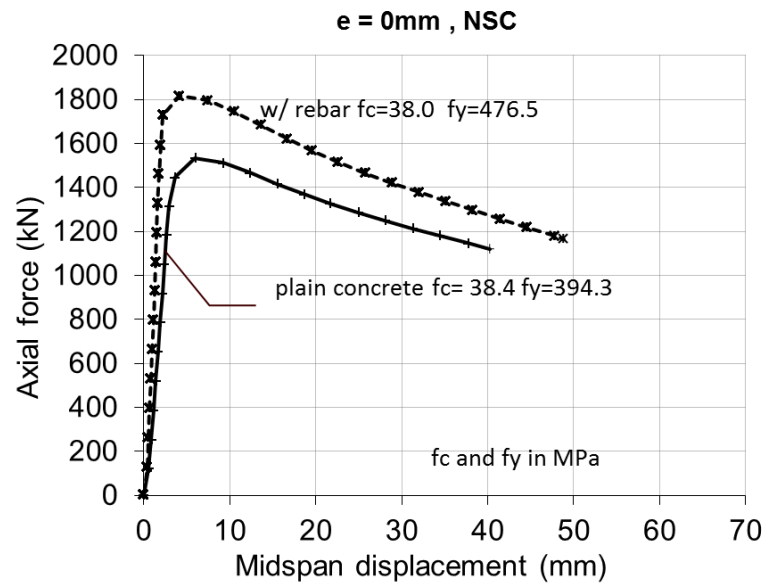

a)

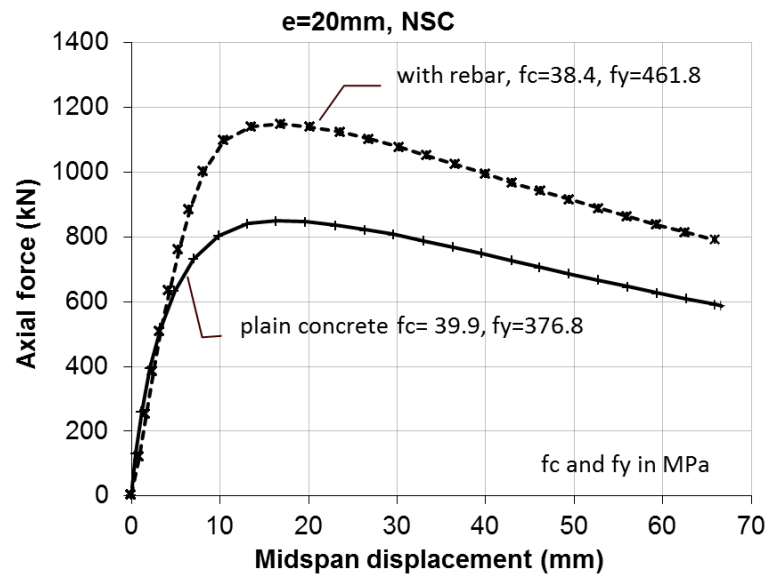

b)

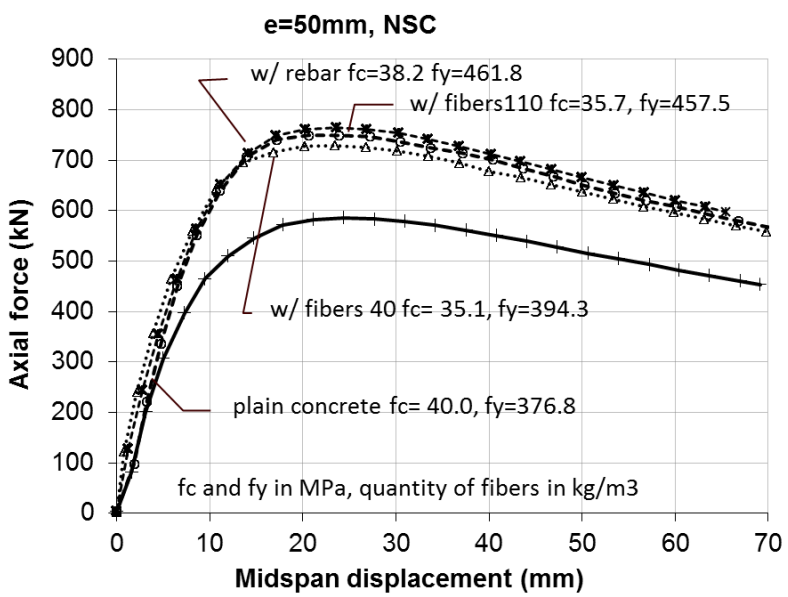

c)

Fig. 4. Behavior of Normal strength concrete tests (NSC). 
Portolés JM, Serra E, Romero ML*. Influence of ultra-high strength infill in slender concrete-filled steel tubular columns. Journal of constructional steel research 2013;86:107-114.

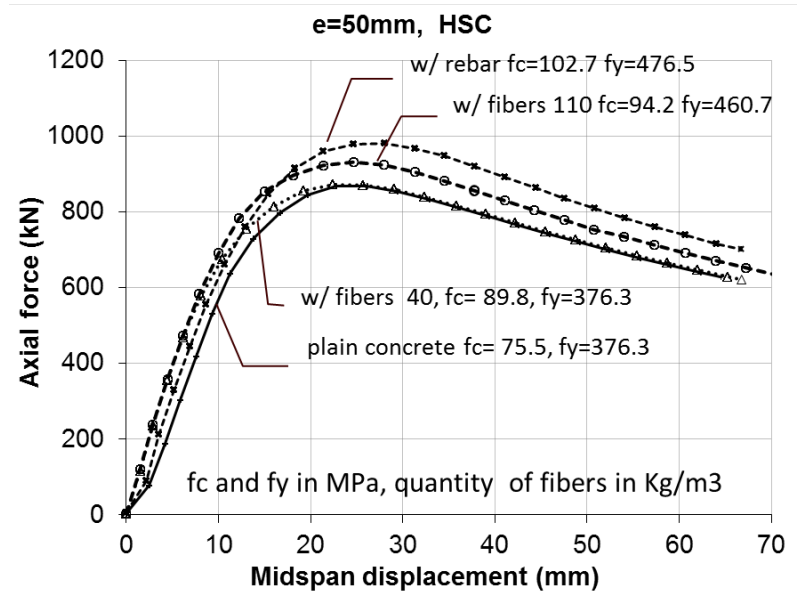

Fig. 5. Behavior of High strength concrete tests (HSC) with large eccentricities. 
Portolés JM, Serra E, Romero ML*. Influence of ultra-high strength infill in slender concrete-filled steel tubular columns. Journal of constructional steel research 2013;86:107-114.

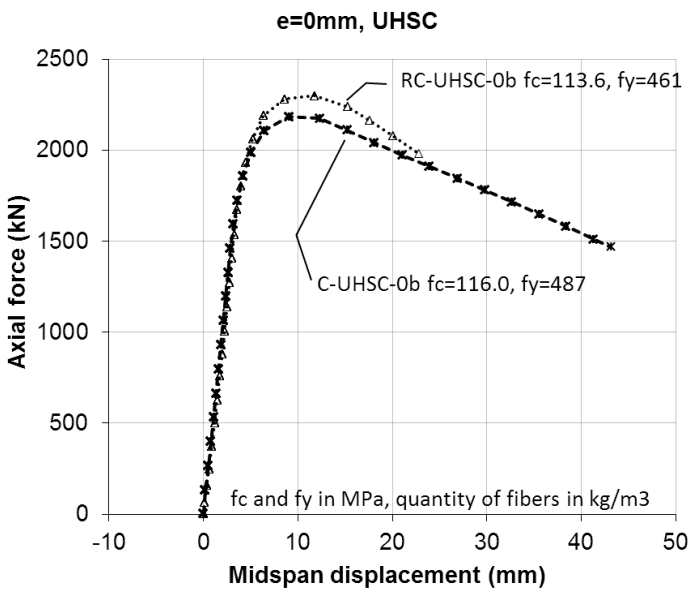

a)

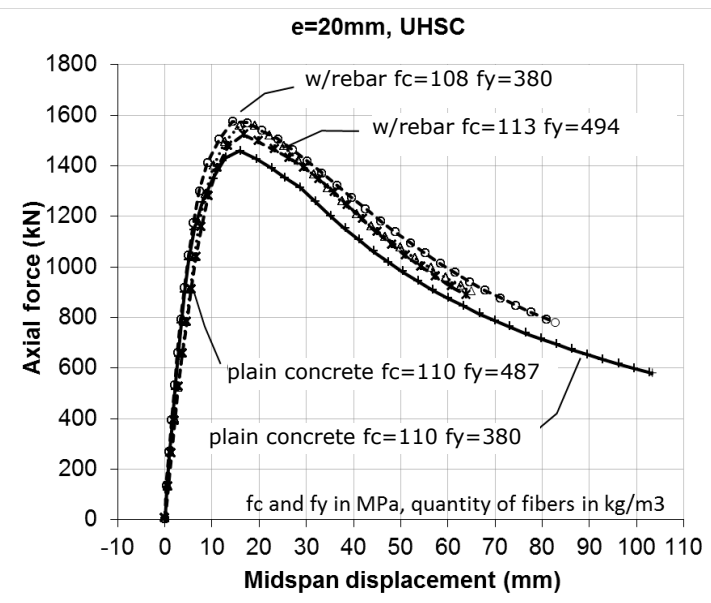

b)

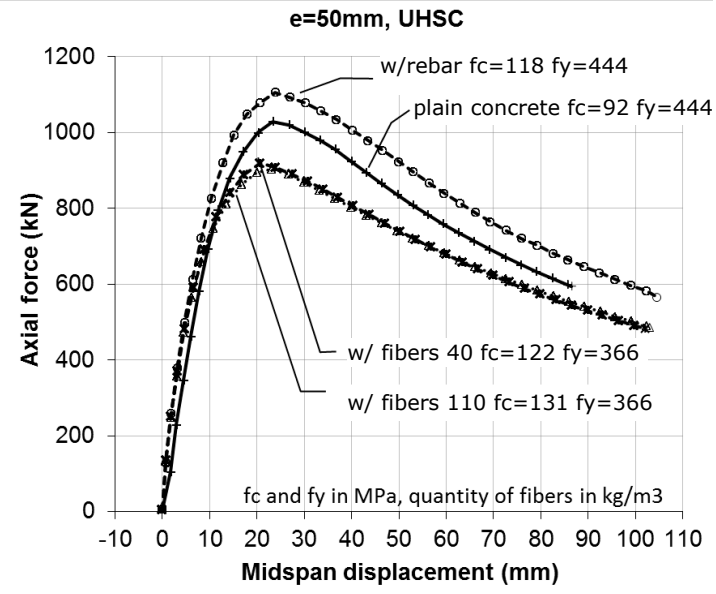

c)

Fig. 6. Behavior of Ultra-high strength concrete tests (NSC). 
Portolés JM, Serra E, Romero ML*. Influence of ultra-high strength infill in slender concrete-filled steel tubular columns. Journal of constructional steel research 2013;86:107-114.

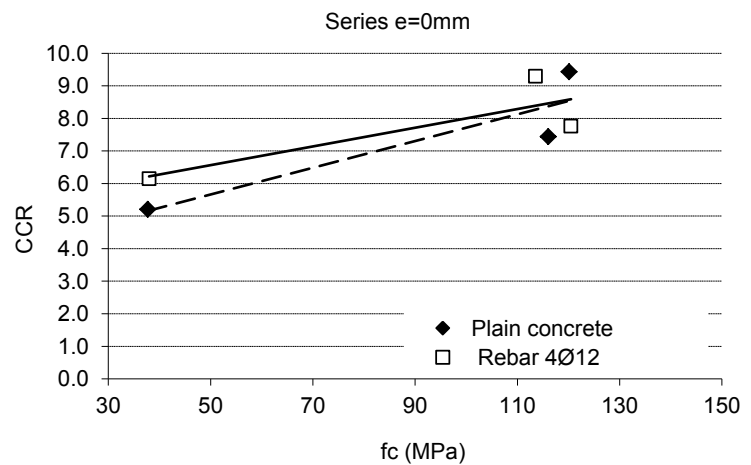

a)

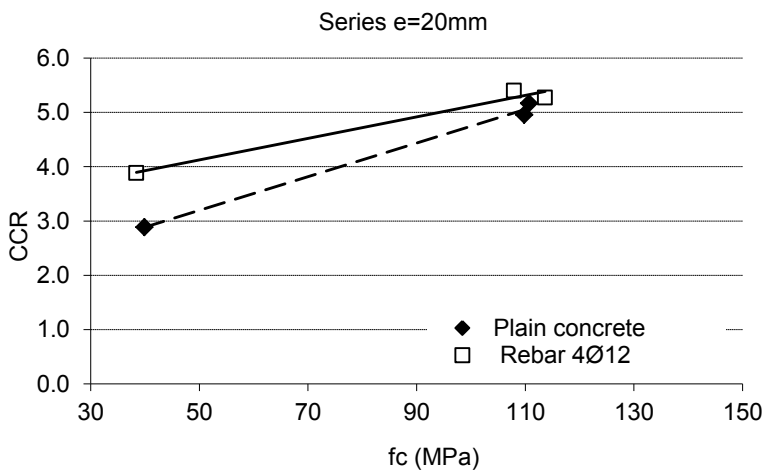

b)

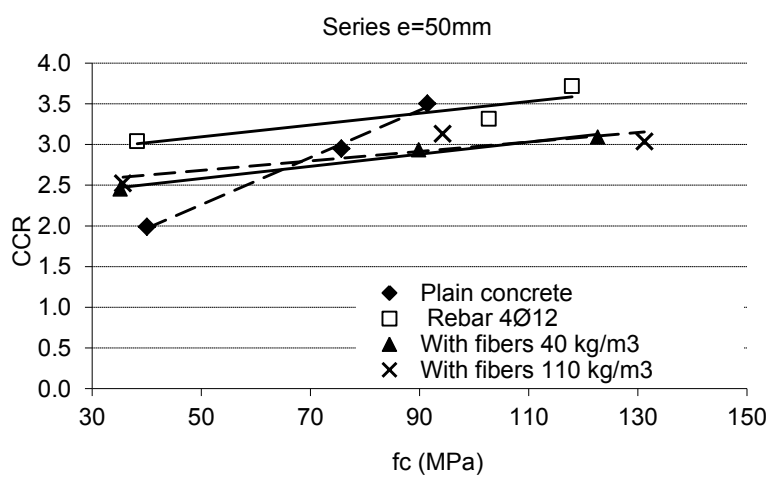

c)

Fig. 7. Concrete contribution ratio (CCR). 
Portolés JM, Serra E, Romero ML*. Influence of ultra-high strength infill in slender concrete-filled steel tubular columns. Journal of constructional steel research 2013;86:107-114.

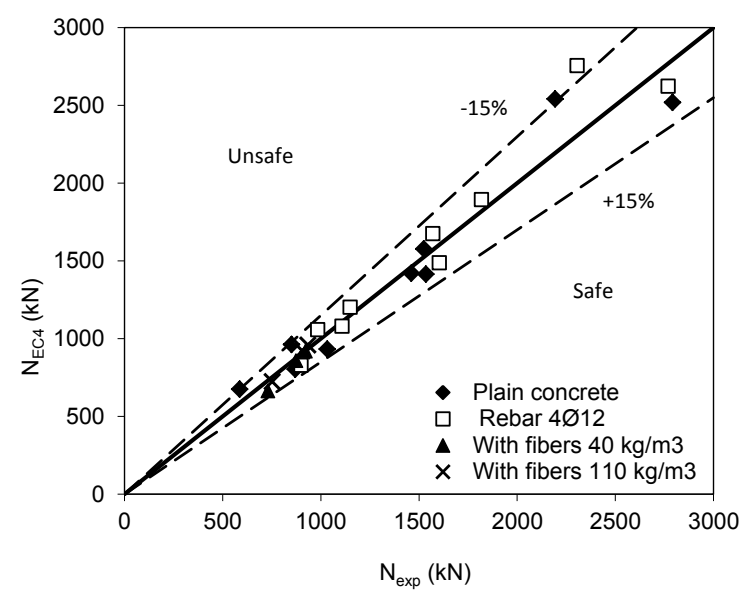

Fig. 8. Comparison of ultimate load $\left(\mathrm{N}_{\mathrm{exp}}\right)$ and Eurocode 4 design provisions $\left(\mathrm{N}_{\mathrm{EC} 4}\right)$ 
Portolés JM, Serra E, Romero ML*. Influence of ultra-high strength infill in slender concrete-filled steel tubular columns. Journal of constructional steel research 2013;86:107-114.

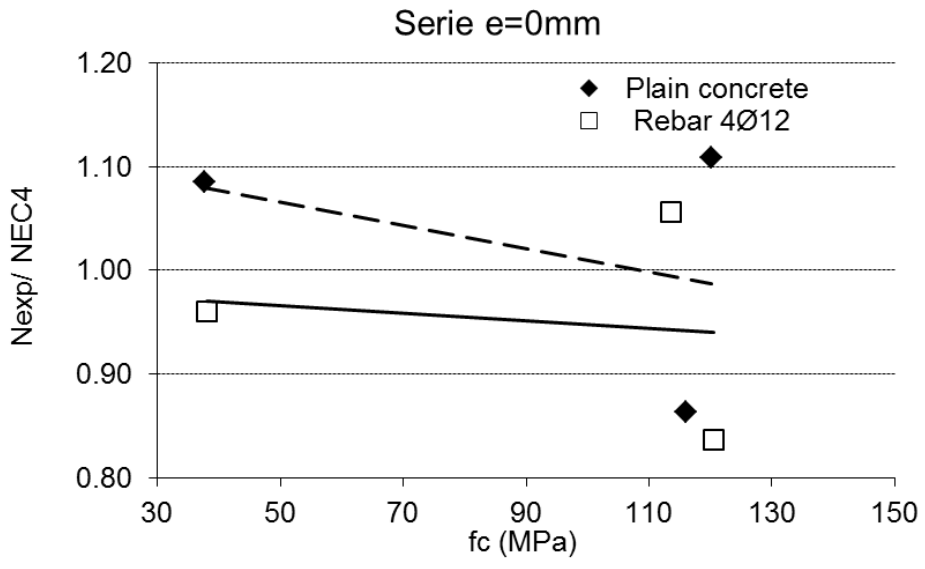

a)

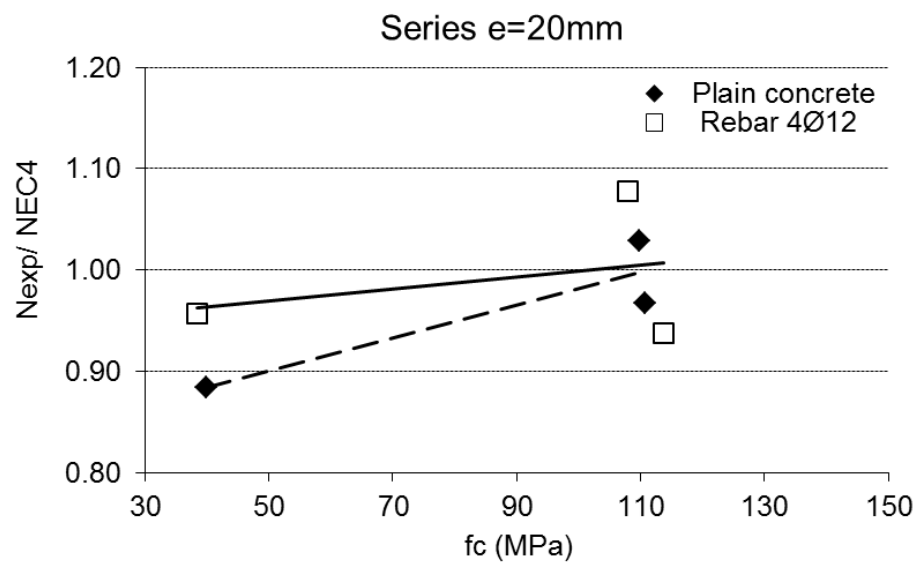

b)

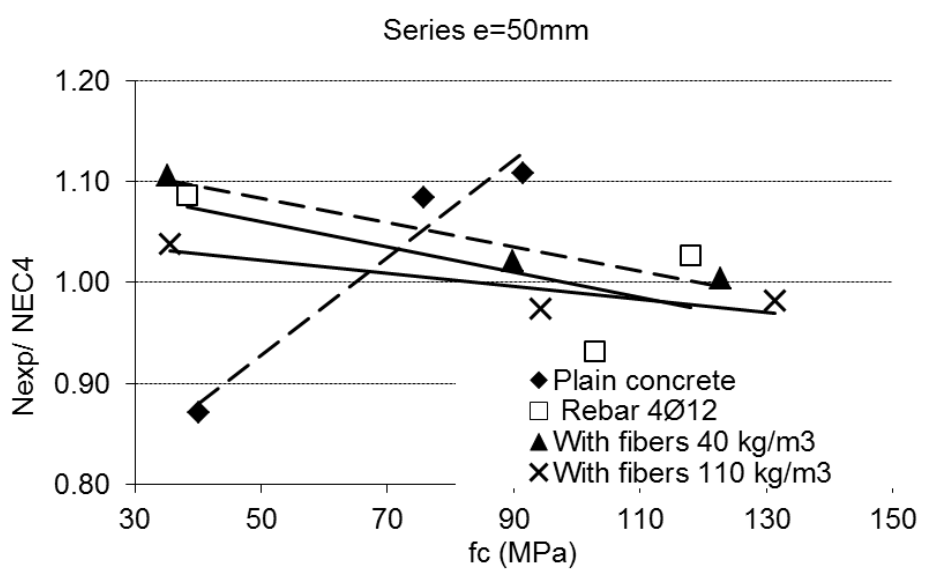

c)

Fig. 9. Error in Eurocode $4\left(\mathrm{~N}_{\mathrm{EC} 4}\right)$ 
Portolés JM, Serra E, Romero ML*. Influence of ultra-high strength infill in slender concrete-filled steel tubular columns. Journal of constructional steel research 2013;86:107-114. 
Portolés JM, Serra E, Romero ML*. Influence of ultra-high strength infill in slender concrete-filled steel tubular columns. Journal of constructional steel research 2013;86:107-114.

Table 1. Test properties and results

\begin{tabular}{|c|c|c|c|c|c|c|c|c|c|c|}
\hline & Id & Name & $\begin{array}{c}\mathrm{e} \\
(\mathbf{m m})\end{array}$ & $\begin{array}{c}\mathbf{f}_{\mathbf{y}} \\
(\mathbf{M P a})\end{array}$ & $\begin{array}{c}\mathbf{f}_{\mathrm{c}} \\
(\mathrm{MPa})\end{array}$ & Infill & $\bar{\lambda}$ & $\begin{array}{l}\mathbf{N}_{\text {EXP }} \\
(\mathbf{k N})\end{array}$ & $\begin{array}{l}\mathrm{N}_{\mathrm{EC4}} \\
(\mathrm{kN})\end{array}$ & $\mathbf{N}_{\text {exp }} / \mathbf{N}_{\text {EC4 }}$ \\
\hline \multirow{8}{*}{$\begin{array}{l}U \\
\mathscr{Z}\end{array}$} & 1 & C-NSC-0 & 0 & 394 & 37.7 & Plain concrete & 0.61 & 1535 & 1414 & 1.09 \\
\hline & 2 & C-NSC-20 & 20 & 377 & 39.9 & Plain concrete & 0.60 & 851 & 963 & 0.88 \\
\hline & 3 & C-NSC-50 & 50 & 377 & 40.1 & Plain concrete & 0.60 & 587 & 674 & 0.87 \\
\hline & 4 & F40 -NSC-50 & 50 & 394 & 35.1 & Steel fibers $40 \mathrm{~kg} / \mathrm{m}^{3}$ & 0.60 & 731 & 661 & 1.11 \\
\hline & 5 & F110-NSC-50 & 50 & 457 & 35.7 & Steel fibers $110 \mathrm{~kg} / \mathrm{m}^{3}$ & 0.63 & 752 & 724 & 1.04 \\
\hline & 6 & RC-NSC-0 & 0 & 477 & 38.0 & Rebar 4Ø12 & 0.71 & 1818 & 1893 & 0.96 \\
\hline & 7 & RC-NSC-20 & 20 & 462 & 38.4 & Rebar $4 \varnothing 12$ & 0.69 & 1150 & 1202 & 0.96 \\
\hline & 8 & RC-NSC-50 & 50 & 462 & 38.2 & Rebar $4 \varnothing 12$ & 0.69 & 900 & 828 & 1.09 \\
\hline \multirow{4}{*}{$\begin{array}{l}U \\
\mathscr{I} \\
\mathcal{I}\end{array}$} & 9 & C-HSC-50 & 50 & 376 & 75.7 & Plain concrete & 0.69 & 870 & 803 & 1.08 \\
\hline & 10 & F40-HSC-50 & 50 & 376 & 89.8 & Steel fibers $40 \mathrm{~kg} / \mathrm{m}^{3}$ & 0.71 & 874 & 856 & 1.02 \\
\hline & 11 & F110-HSC-50 & 50 & 461 & 94.2 & Steel fibers $110 \mathrm{~kg} / \mathrm{m}^{3}$ & 0.76 & 934 & 959 & 0.97 \\
\hline & 12 & RC-HSC-50 & 50 & 477 & 102.7 & Rebar $4 \varnothing 12$ & 0.80 & 985 & 1058 & 0.93 \\
\hline \multirow{12}{*}{ 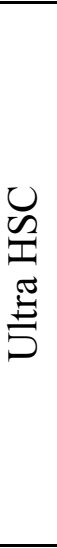 } & 13 & C-UHSC-0* & 0 & 457 & 120.1 & Plain concrete & 0.85 & 2792 & 2519 & $*$ \\
\hline & 14 & C-UHSC-0-b & 0 & 487 & 116.0 & Plain concrete & 0.86 & 2193 & 2541 & 0.86 \\
\hline & 15 & C-UHSC-20 & 20 & 380 & 109.8 & Plain concrete & 0.76 & 1462 & 1421 & 1.03 \\
\hline & 16 & C-UHSC-20-b & 20 & 487 & 110.7 & Plain concrete & 0.80 & 1525 & 1576 & 0.97 \\
\hline & 17 & C-UHSC-50 & 50 & 444 & 91.4 & Plain concrete & 0.74 & 1033 & 932 & 1.11 \\
\hline & 18 & F40-UHSC-50 & 50 & 366 & 122.6 & Steel fibers $40 \mathrm{~kg} / \mathrm{m}^{3}$ & 0.77 & 921 & 917 & 1.00 \\
\hline & 19 & F110-UHSC-50 & 50 & 366 & 131.2 & Steel fibers $110 \mathrm{~kg} / \mathrm{m}^{3}$ & 0.79 & 905 & 921 & 0.98 \\
\hline & 20 & RC-UHSC-0* & 0 & 494 & 120.5 & Rebar 4Ø12 & 0.90 & 2305 & 2756 & $*$ \\
\hline & 21 & RC-UHSC-0-b & 0 & 461 & 113.6 & Rebar 4Ø12 & 0.87 & 2769 & 2623 & 1.06 \\
\hline & 22 & RC-UHSC-20 & 20 & 494 & 113.6 & Rebar $4 \varnothing 12$ & 0.83 & 1571 & 1676 & 0.94 \\
\hline & 23 & RC-UHSC-20-b & 20 & 380 & 107.9 & Rebar 4Ø12 & 0.78 & 1604 & 1487 & 1.08 \\
\hline & 24 & RC-UHSC-50 & 50 & 444 & 118.0 & Rebar $4 \varnothing 12$ & 0.82 & 1108 & 1079 & 1.03 \\
\hline & & & & & & & & & $\begin{array}{c}\text { Mean } \\
\text { Std. Dev. }\end{array}$ & $\begin{array}{l}1.00 \\
0.07\end{array}$ \\
\hline
\end{tabular}

Where $\mathrm{C}$ stands for plain concrete, $\mathrm{F}$ for steel fiber reinforced concrete and $\mathrm{RC}$ for barreinforced concrete.

All the specimens in this table with $D=159 \mathrm{~mm}, t=6 \mathrm{~mm}, L=2135 \mathrm{~mm}$. 
Portolés JM, Serra E, Romero ML*. Influence of ultra-high strength infill in slender concrete-filled steel tubular columns. Journal of constructional steel research 2013;86:107-114.

Table 2. Mix proportions

\begin{tabular}{lccccccccc} 
Type of infill & 30 & 90 & 130 & 30 & 90 & 130 & 30 & 90 & 130 \\
& & & & F40 & F40 & F40 & F110 & F110 & F110 \\
\hline Cement $(\mathrm{kg} / \mathrm{m} 3)$ & 375 & 475 & 800 & 375 & 475 & 800 & 375 & 475 & 800 \\
Water $(\mathrm{L} / \mathrm{m} 3)$ & 225 & 142 & 150 & 225 & 142 & 150 & 225 & 142 & 150 \\
Sand $(\mathrm{kg} / \mathrm{m} 3)$ & 778 & 855 & 800 & 772 & 850 & 793 & 953 & 910 & 781 \\
Gravel 4-7 mm (kg/m3) & 651 & 634 & 630 & 646 & 628 & 625 & 534 & 594 & 615 \\
Gravel 7-12 mm (kg/m3) & 304 & 332 & - & 302 & 329 & - & 197 & 280 & - \\
Steel fibers $(\mathrm{kg} / \mathrm{m} 3)$ & - & & & 40 & 40 & 40 & 110 & 110 & 110 \\
Silica fume $(\mathrm{kg} / \mathrm{m} 3)$ & - & 47.5 & 120 & - & 47.5 & 120 & - & 47.5 & 120 \\
Super-plasticizer $(\mathrm{kg} / \mathrm{m} 3)$ & - & 10.7 & 26.3 & - & 10.7 & 26.3 & 1 & 10.7 & 26.3 \\
Cohesive agent $(\mathrm{kg} / \mathrm{m} 3)$ & - & - & & - & - & & 1 & - & \\
\hline
\end{tabular}

